\title{
EMPIRICAL VERIFICATIONS OF WEB-LEARNING ENVIRONMENT TO ENHANCE LEARNING EFFECTIVENESS AND MOTIVATION IN MECHANICAL DRAWING
}

\author{
Tsutomu Sekine (iD) \\ Seikei University (Japan) \\ ts_s@outlook.com
}

Received October 2019

Accepted February 2020

\section{Abstract}

In mechanical drawing class, it is a problem that a lecturer has students get a wide range of knowledge and skills in a class whose time and place are limited in a semester. The situation surrounding the classes has led to insufficient understanding of students. Accordingly, it has been desired to reveal an effective learning method in mechanical drawing class. In this study, a web-learning environment was created on the basis of motivation-oriented teaching method using ARCS model and Gagne's 9 events of instruction. Then, the web-learning environment was introduced into mechanical drawing class, and the effectiveness was investigated with the comparison of results from paper-based and web-based tests. After that, learning motivation was also assessed using ARCS evaluation sheet. From the results, there existed the advantage of using web-learning environment. In addition, it was remarkable that attention-related factors greatly contributed the enhancement of learning motivation.

Keywords - Mechanical drawing, E-learning, ARCS model, Gagne's 9 events of instruction, Learning motivation.

\section{To cite this article:}

Sekine, T. (2020). Empirical verifications of web-learning environment to enhance learning effectiveness and motivation in mechanical drawing. Journal of Technology and Science Education, 10(2), 179-189. https://doi.org/10.3926/jotse.856

\section{Introduction}

Among various subjects with respect to mechanical engineering, design and drawing allow students to learn important knowledge and skills related to manufacturing. The knowledge and skills are particularly essential to obtain a design solution satisfying required specification for designing a machine in practice. Although the time of education is not necessarily sufficient, the course hours have been gradually decreasing. The fact indicates that it is getting difficult for students to learn a wide range of knowledge and skills in mechanical design and drawing. The tendency will probably continue from now on, so that the students' understanding would inevitably deteriorates more and more. From the backgrounds, there are studies with many kinds of viewpoints regarding design and drawing. Huerta, Kus, Unver, Aslan, Dawood, Kofoglu et al. (2019) developed an AR/VR application to support the learning and teaching of design and engineering students in education and industry. Azodo (2017) studied the effects of attitude 
related to engineering students' learning in engineering drawing. Halim, Yasin and Ishar (2012) discussed students' and teachers' perception on an innovative teaching method of engineering drawing subject at secondary school level. In addition, they reported the effects of teaching problem-solving strategies in the engineering drawing subject on student achievement, students' knowledge of problem-solving and students' problem-solving skills (Yasin, Halim \& Ishar, 2012). Katz (2015) proposed integrated thinking as a new approach and showed how it can be applied to various mechanical engineering courses for undergraduate students. Adanez and Velasco (2002) gave an investigation of a visualization psychometric test that could facilitate an early diagnosis concerning the academic performance of technical drawing students. dos Santos, Gonçalves, de Oliveira and Silva (2018) reported a new structure in the educational methodology related to project-based learning. However, the efficient learning environment has been still desired to provide instructive opportunities for not only overcoming the related problems but also obtaining a lot of knowledge and skills within a reasonable time scale.

These days, various information technologies for education are being widely used to enhance the learning and teaching effectiveness. Especially, e-learning is well known as a useful method with several merits. To name a few, we can learn what we want to know without a lecturer. It can provide ubiquitous learning environment available from mobile devices. The system enables us to use a wide variety of learning contents. Individual-oriented instructions also act as a helpful function in some cases. In creating a web-learning environment, each component such as web design is created situationally with learning theory to enhance both learning motivation and learning effectiveness.

Gagne's theory of instruction is one of the effective theories in education. The related works have been reported so far in a variety of fields. Baba, Sale and Zirra (2017) created student-centered learning environment designed using Gagne's theory of instruction, and the multimedia program was applied to education in secondary school. Mei, Ramli and Alhirtani (2015) studied Gagne's nine approaches in teaching Arabic to non-native speakers. Their work led to the importance in education and teaching. Lee and Lee (2012) developed e-learning content for advertising theory applying Gagné's nine events of Instruction. The content worked properly in the advertising classes. Khadjooi, Rostami and Ishaq (2011) investigated the applicability of Gagne's model of instructional design in teaching psychomotor skills. Gagne's strategy was also used to a development of a conceptual understanding in mathematics (Erlinda \& Surya, 2017). Kutlu and Menzi (2013) examined the effect of internet-based instruction with Gagne's theory in primary schools. Cheung (2016) also studied a teaching method with Gagne's theory for medical procedure. Al-Shalabi, Andraws, Alrabea and Kumar (2012) proposed a V model of E-learning using the well-known Gagne nine steps for quality education.

Meanwhile, ARCS model was proposed by Keller (1987). ARCS stands for Attention, Relevance, Confidence, and Satisfaction. The model is one of the useful tools for instructional design to improve learning motivation directly. The overview was given by Arora and Sharma (2018), and many types of contribution have been made with ARCS model. The relationship between ARCS model and persuasive strategies was investigated to provide empirical insight into the mechanism through which persuasive technologies persuade (Orji, Reilly, Oyibo \& Orji, 2018). Zhang (2017) designed a micro-lecture teaching platform based on ARCS model. The results showed the suitable characteristics of platform. Lee and Kim (2012) developed Web-based courseware using ARCS model for lower elementary level, number sense concepts. Effectiveness of ARCS Model of Motivational Design was discussed to overcome the motivational problem of distance learning students (Malik, 2014). Huett, Kalinowski, Moller and Huett (2008) examined the improvement of motivation and retention of online students through the use of ARCS-based e-mails. Kurt and Keçik (2017) studied the effects of ARCS model on students' motivation to learn English. Although these approaches have been demonstrated to be very useful in education, authors are unaware of the applied study of ARCS model in mechanical design and drawing. 
The purpose of this study is to demonstrate the availability of two educational approaches in mechanical drawing education. In this study, a web-learning environment with instruction of the third angle projection method was created based on motivation-oriented teaching method using ARCS model and Gagne's 9 events of instruction. Then, it was introduced into a mechanical drawing class for Japanese students in our university. After that, the effectiveness was investigated with the comparison of results from two types of evaluation tests. Moreover, the influence of web-learning environment on learning motivation was clarified by questionnaire investigation with a modified ARCS evaluation sheet.

\section{Design of a Web Learning Environment for Mechanical Drawing}

There are a lot of research works associated with ARCS model (e.g., Keller, 2010). As one of the outcomes, a motivation-oriented instruction and design procedure were proposed from a problem-solving perspective of learning motivation (Suzuki, 1995). Gagne's 9 events of instruction have drawn academic attention in pedagogical field since it can enhance students' learning motivation. With the proposed strategy, the related studies have been conducted to reveal learning effectiveness from various viewpoints (e.g., Suzuki, 2000; Wang, Ikeda \& Li, 2007). Web-learning environment developed in this study was created based on the two instructional design theories. We created web-learning environment through applying some illustrations extracted partially from a test book for mechanical drawing (Hayashi, 2013). The purpose of creating a website was to enhance learning effectiveness and learning motivation of students attending a class of mechanical drawing in our university.

Top page is firstly displayed as shown in Figure 1 when a user accesses the website. This page expresses the site map used for website's design. The learning contents were classified into several topics in the site map. This website design is useful to learn and search what learner would like to know repeatedly. The next page was designed as shown in Figure 2. This page is placed on Lesson 1. Here, example problem is provided to make learners aware of learning objective. Essential information is subsequently given in Lesson 2. Figure 3 expresses a part of Lesson 2. The third angle projection method is explained with effective illustrations to assist an understanding of projection drawing method. In addition, some video contents were prepared as shown in Figure 4. The deficient information in two-dimensionally displayed contents is complemented by using the contents, and they enable us to learn practical drawing techniques in mechanical design. A learner can intuitively interpret essentials through the contents in each webpage based on problem-solving approach.

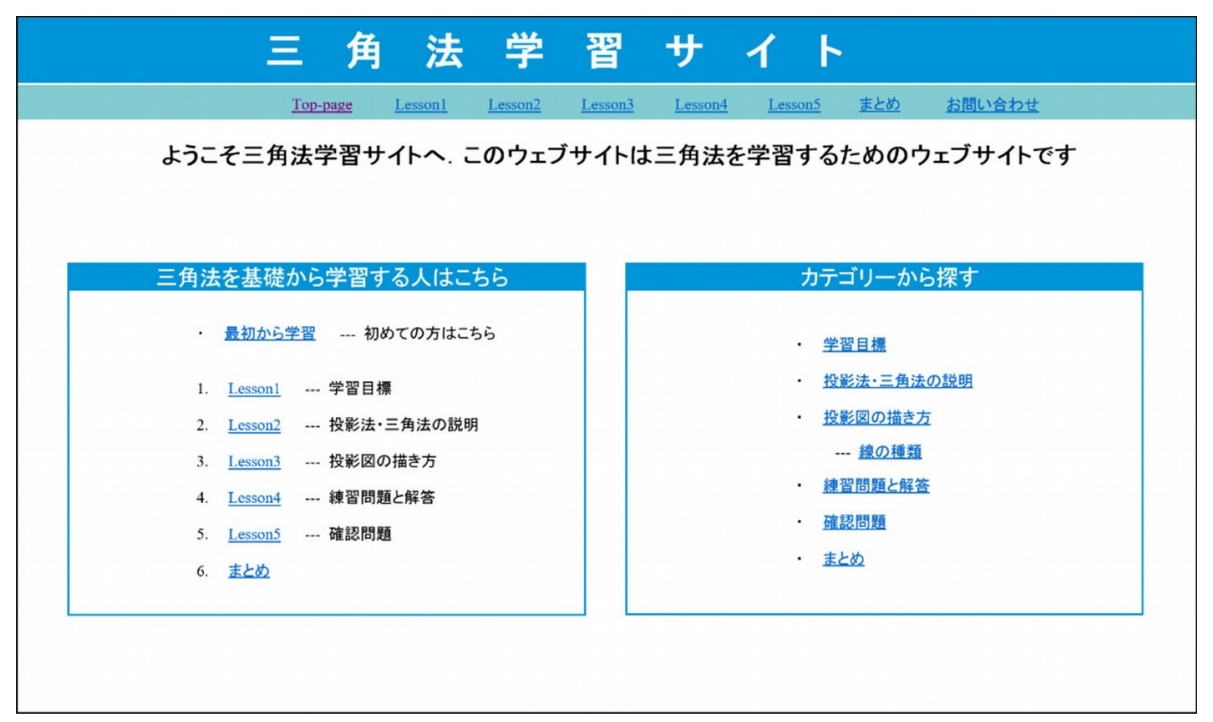

Figure 1. The top page of website 


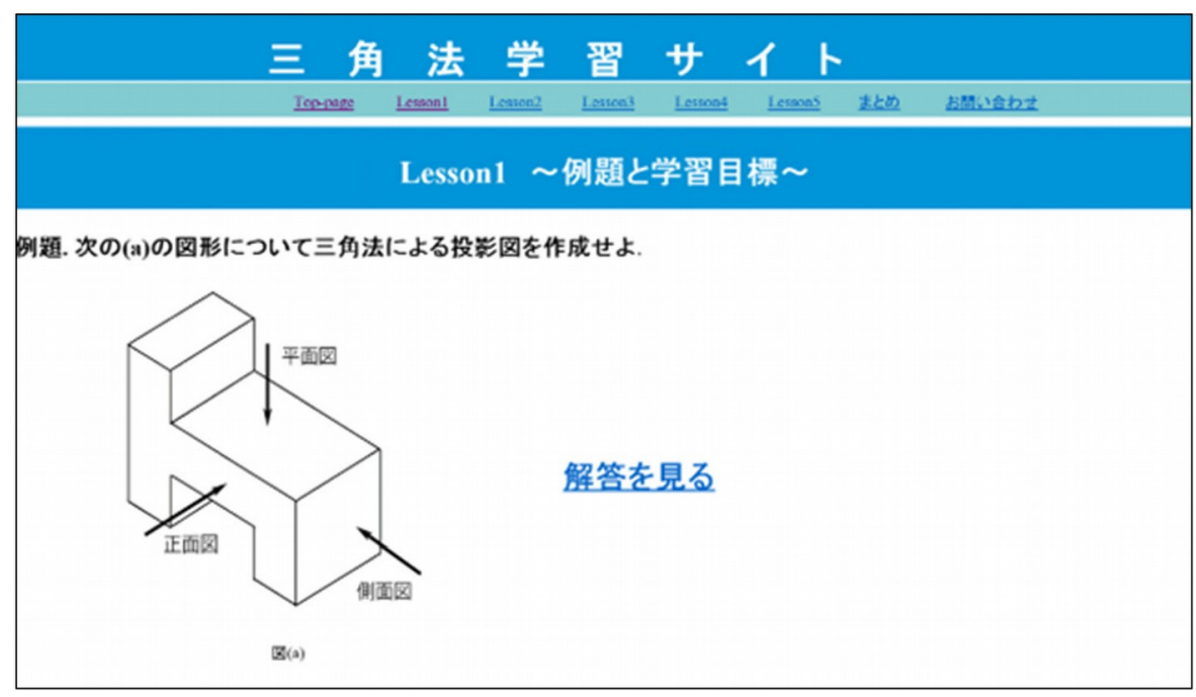

Figure 2. The partial appearance of example problem and learning objective in Lesson 1

\section{3. 第三角法}

図(g)に示すように，品物の手前 に画面を設けて, この画面に投 影する方法を第三角法（third angle projection method) と いい, 機械製図ではこの投影法 を用いる。第三角法は，図を描 いたり，見たりするとき，対応 する図が隣どうしに配置される ので，図が見やすく，描きやす い. 図(h)は，第三角法による 投影図の配置を示す。

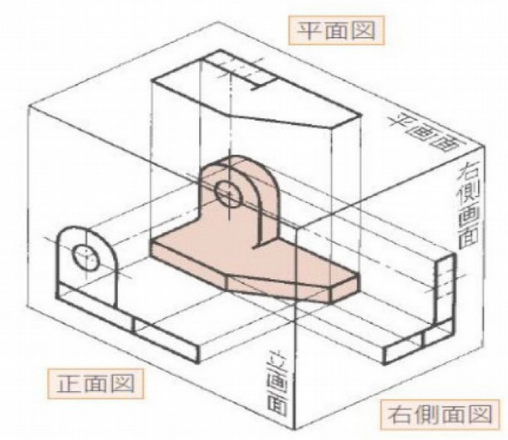

図(g)

(a)

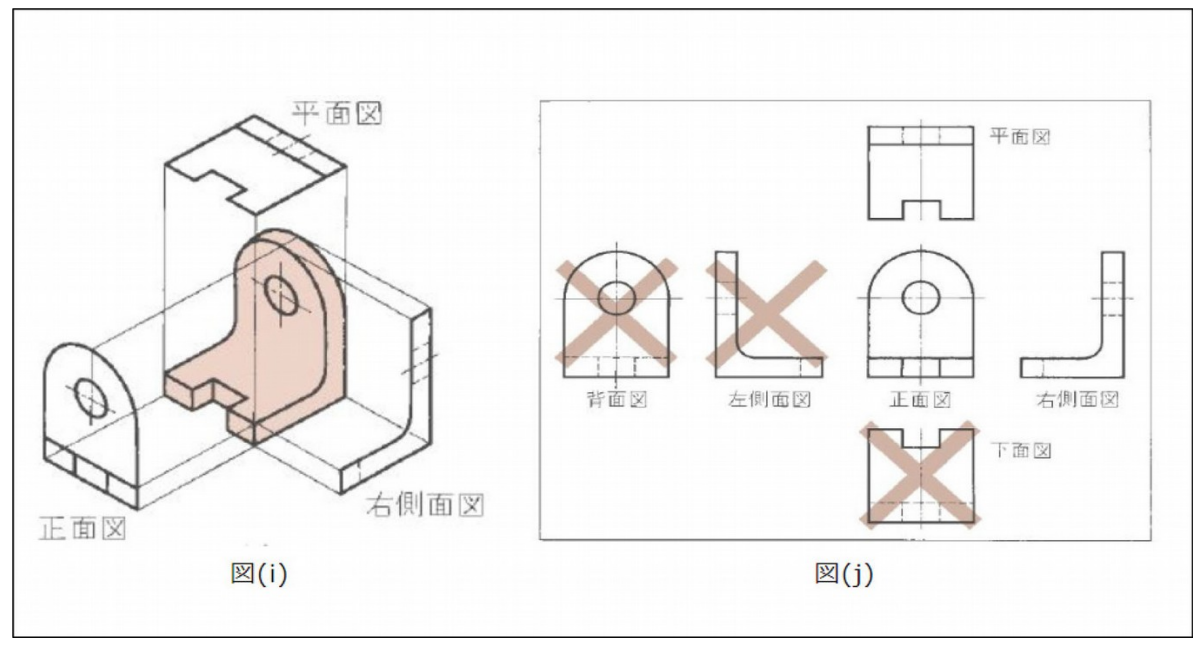

(b)

Figure 3. The partial appearance of learning contents in Lesson 2. (a) A partial explanation of the third angle projection method. (b) A schematic illustration for suitable selection of projection drawing 


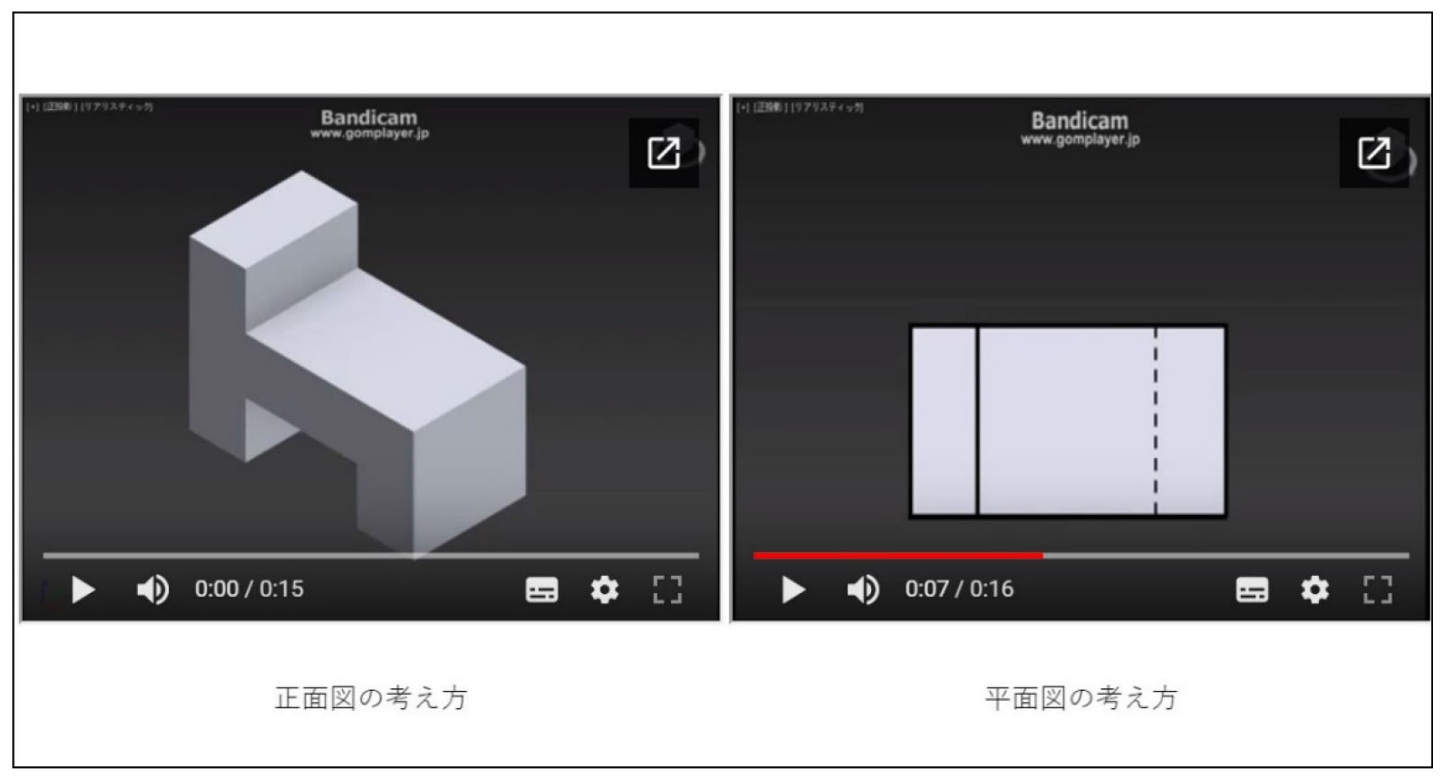

Figure 4. An example of video contents to learn the third angle projection method

Lesson 3 illustrates essential information for 3-view drawing. After that, Lesson 4 provides several problems similar to the example problem in Lesson 1. One of the problems is shown in Figure 5. This page is very useful to give learners experience of various exercises. The practices can be repeatedly implemented for 3-view drawing based on the third angle projection method; moreover, these answers are checkable with reference to video contents as exhibited in Figure 6. Finally, evaluation test is given in Lesson 5 to check learner's understanding for the third angle projection method. Figure 7 shows an example of the tests. The test was also designed for a practicality evaluation of web-learning environment used in mechanical drawing class. The answers are quickly saved to a file on a cloud system.

The other advantages were made for further convenience. In each page, the hyperlink for next page is placed on the bottom of current page. We can accordingly go to the next web page by using the hyperlinks. The page for summary was also designed to give a rise to learners' interest in mechanical design. In addition, the page for inquiry was created for learners who would like to get the advanced information.

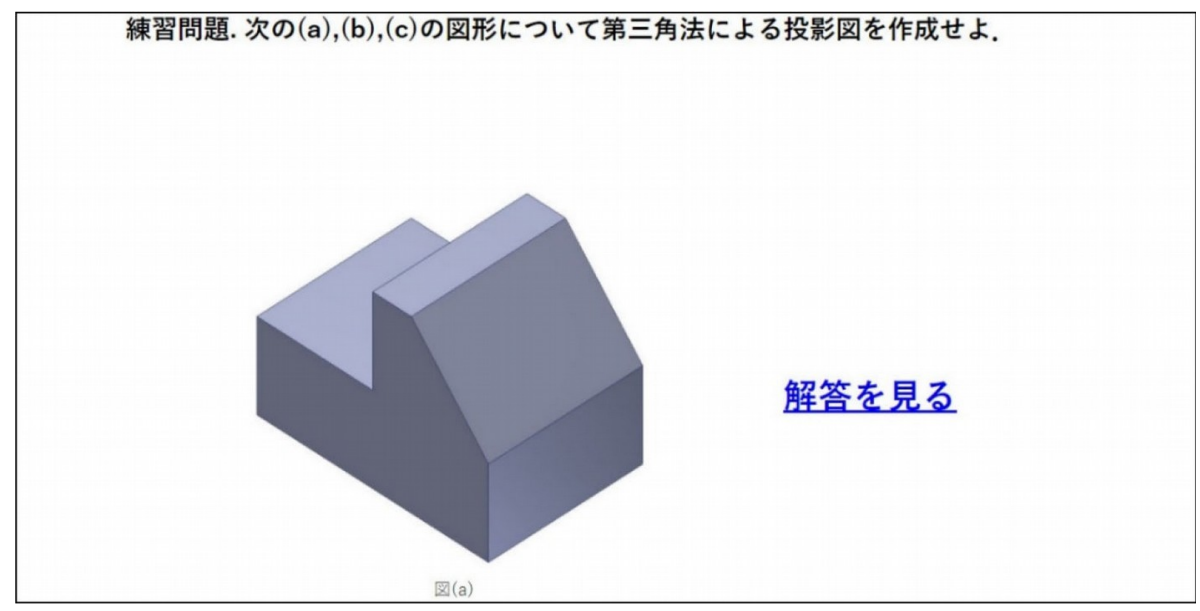

Figure 5. An example of several problems similar to the example problem 


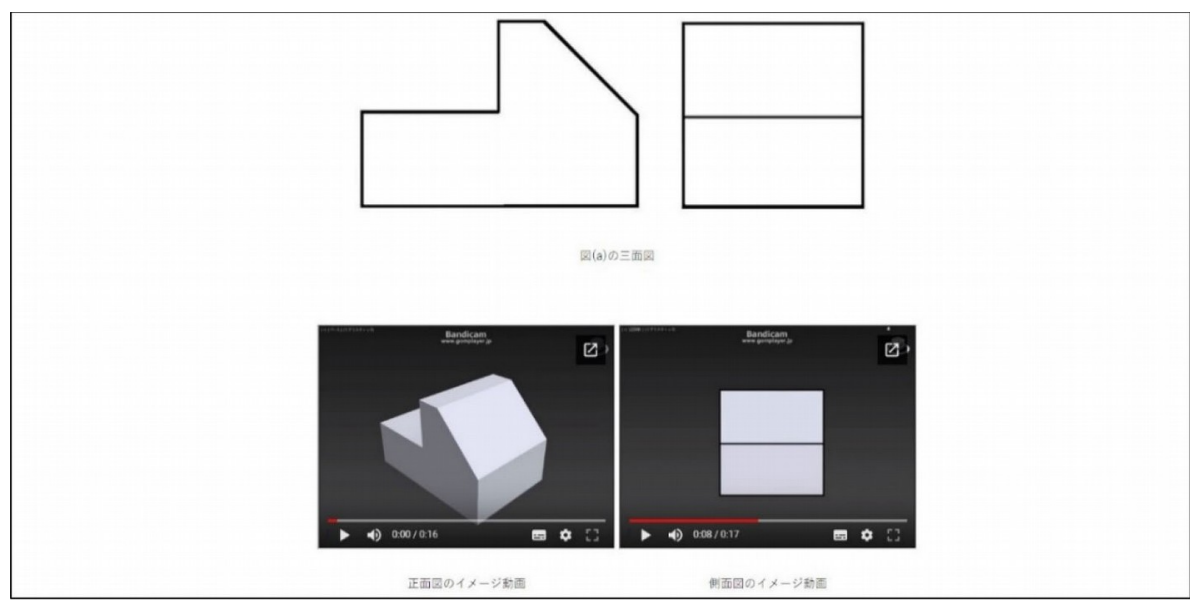

Figure 6. A part of the answer for one of the similar problems

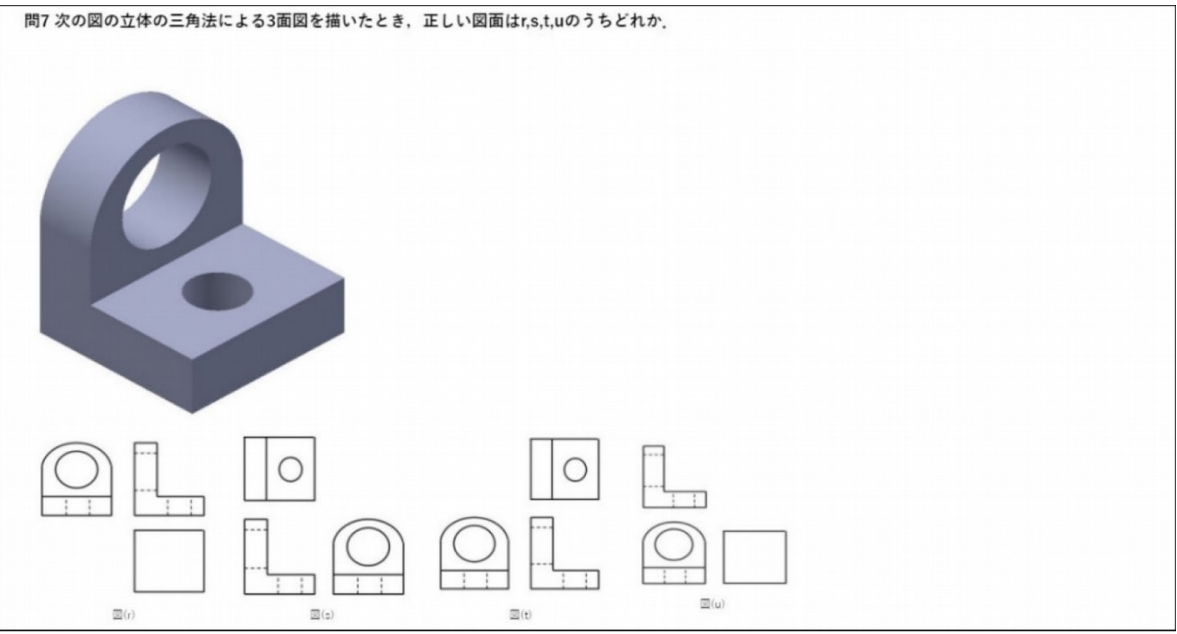

Figure 7. An example of evaluation test

\section{Demonstrations and Evaluations}

\subsection{Introduction of Web-Learning Environment in Mechanical Drawing Class}

One of the mechanical drawing classes in beginner's level is annually held for first-year students in our department. There always exist more than 100 Japanese students attending the class, and almost all of the students do not have any knowledge associated with mechanical design. Web-learning environment created in this study was introduced into the class for validation through a practical application. The validation was performed in the past two years. A paper-based evaluation test was used in the former year, while a web-based evaluation test was given in the latter year. The difficulty levels including the time limit of each test were adjusted to the same degree. The third angle projection method is explained with its practical training after some fundamental knowledge necessary for mechanical drawing is offered in the previous classes. In the conventional class, students had taken a paper-based evaluation test as shown in Figure 8. The test-takers had to answer some questions to check the understanding of knowledge related to the third angle projection method. They also had to depict the 3-view drawings for each projection view. The answers and drawings were quantitatively scored by experienced designers. The depth of understanding for the third angle projection method was inevitably reflected in the 3-view drawings.

On the other hand, students different from the former ones took a web-based evaluation test explained in the previous section after they also learned some fundamental knowledge necessary for mechanical drawing. In the both years, the textbook and reference books were announced at the beginning of mechanical drawing class. The test preparation can accordingly be made with these materials. In addition, web-learning environment was available anytime and everywhere since the test was noticed in the latter 
year. The answers were automatically collected and scored in the web-learning environment with a cloud system. The scored results can reveal the depth of understanding in the third angle projection method. The effectiveness in introducing the environment was assessed based on the comparison of two evaluation tests.

\section{三角法による投影図法演習要領（冬休み宿題 $)$}

1)

1. 図 1〜図 4 までの図形について三角法による投影図を完成させよ.

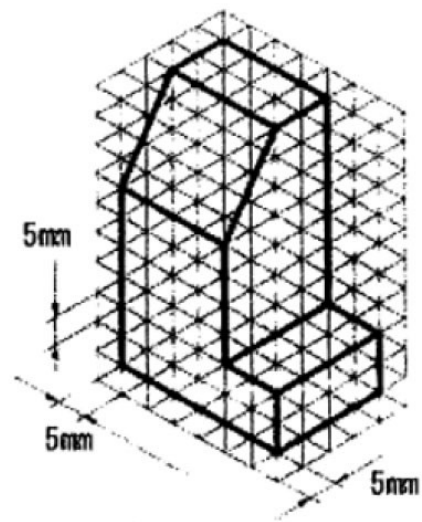

図 1

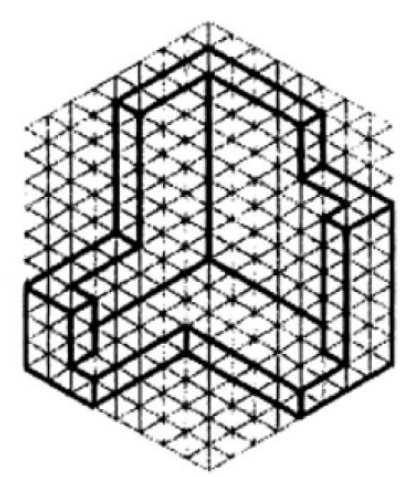

図 3

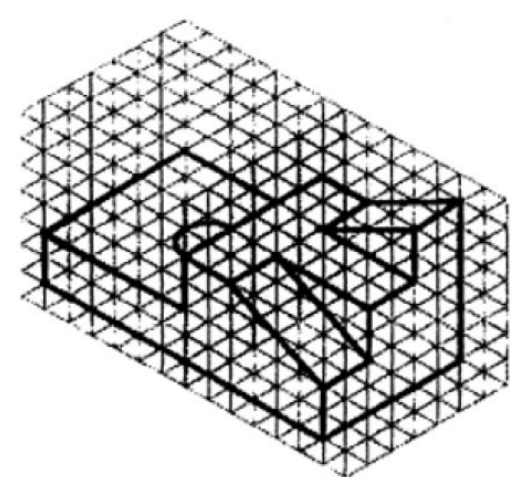

図 2

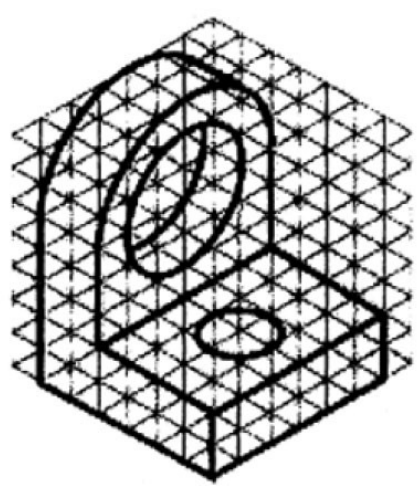

図 4

Figure 8. An example of evaluation test

\subsection{Investigation of Learning Motivation}

The investigation was made for the influence of web-learning environment on learning motivation. The participants were 10 Japanese students belonging to school of engineering in our university. Their ages were from 21 to 22 years old. All the participants had already taken mechanical drawing class when they were first-year student. Accordingly, they had the relevant knowledge in mechanical drawing, while there were individual differences in the amount of knowledge. In the investigation, two types of problems were assigned for each student. The one is multiple choice questions to check the fundamental knowledge regarding the third angle projection method. These questions were associated with not only the relevant knowledge, but also an interpretation of three-dimensional shape. The other is to make 3-view drawing from an isometric projection. A fundamental assignment to create the drawing on a paper was set with reference to those in a paper-based evaluation test. The difficulty levels in each question were adjusted to the same degree. 
In the test, the participants were classified into two groups. To review the relevant knowledge in mechanical drawing, the textbook and reference books were available for the participants in each group. In addition, the only one group was allowed to use web-learning environment. Then, the questions were assigned for each participant. The answers for multiple choice questions were verified after the test, and the drawings were quantitatively scored by experienced designers.

Questionnaire investigation were also made for all the test-takers. In the questionnaire, we used ARCS evaluation sheet including 14 questions based on 4 factors of ARCS model (e.g., Murakawa, Sakaguchi \& Imanaka, 2014). This sheet had Likert scale of one to five in each question. Mann-Whitney U test was used to detect a significant difference due to the small number of samples. Learning motivation was measured based on subjective evaluation by the questionnaire for the test-takers.

\section{Results and Discussions}

\subsection{Effectiveness of Web-Learning Environment in a Mechanical Drawing Class}

Table 1 shows the comparative result of two evaluation tests. The correct answer rate was calculated based on the average value of all scored results. It was found that the correct answer rate in the latter year was really higher than that in the former year. The effectiveness of web-learning environment was numerically obvious from the result, while there were several differences between a paper-based and web-based evaluation test. When we checked the system usage of web-learning environment in the latter year, almost all of the students used the entire contents explained in the previous section before the evaluation test.

\begin{tabular}{|l|r|r|}
\hline & Former year & \multicolumn{1}{c|}{ Latter year } \\
\hline Correct answer rate & $53.8 \%$ & $87.6 \%$ \\
\hline Number of research participants & 146 & 108 \\
\hline
\end{tabular}

Table 1. Correct answer rates in each evaluation test

As described above, the web-learning environment was organized with Gagne's 9 events of instruction which could give students the effective learning procedure to obtain the necessary knowledge. Thus, it is considered that the effective learning procedure can improve learning effectiveness even in mechanical drawing class. On the other hand, the correct answer rate in the former year was almost half although students should use textbook and reference books in the test preparation. The fact implies two causes. The one is that it is difficult for beginners to grasp key learning points in mechanical drawing since there are too much relevant knowledge to make a suitable drawing. The other is that the learning order designed by students themselves is doubtful to obtain the relevant knowledge efficiently. From the result with implications, learning contents organized using Gagne's 9 events of instruction are invaluable for learning the essential knowledge in mechanical drawing. However, it must have been relatively easy for students to get tired with learning the contents when there is too much relevant knowledge to be learned. In spite of that, it was notable that high completion rate was achieved in web-learning environment. We attempted to investigate the interesting point through the next test in a different manner.

\subsection{Influence of Web-Learning Environment on Learning Motivation}

Questionnaire with ARCS evaluation sheet was assigned for each test-taker to investigate an influence of web-learning environment on learning motivation. Table 2 shows each average score calculated from the results of subjective evaluation by the questionnaire after the test. In the table, the mean of each average score in all questions was 3.89 for the group using web-learning environment. The standard deviation was 0.51. In contrast, the mean of each average score in all questions was 3.03 for the other group. The standard deviation was 0.59 . 


\begin{tabular}{|l|l|r|r|}
\hline Question & \multicolumn{1}{|c|}{ ARCS classification } & $\begin{array}{c}\text { Without web learning } \\
\text { environment }\end{array}$ & $\begin{array}{c}\text { With web learning } \\
\text { environment }\end{array}$ \\
\hline Q1 & A: Attention & 2.80 & 3.80 \\
\hline Q2 & A: Perceptual evocation & 4.40 & 4.60 \\
\hline Q3 & A: Evocation of inquisitive mind & 3.20 & 4.20 \\
\hline Q4 & A: Variability & 3.00 & 3.80 \\
\hline Q5 & R: Relevance & 3.00 & 4.20 \\
\hline Q6 & R: Familiarity & 2.40 & 3.40 \\
\hline Q7 & R: Conform with motivation & 3.25 & 4.00 \\
\hline Q8 & R: Purpose directivity & 2.75 & 3.60 \\
\hline Q9 & C: Confidence & 1.75 & 3.00 \\
\hline Q10 & C: Learning desire & 3.25 & 4.60 \\
\hline Q11 & C: Opportunity of success & 3.50 & 4.00 \\
\hline Q12 & C: Personalization of control & 3.25 & 3.00 \\
\hline Q13 & S: Satisfaction & 2.75 & 4.40 \\
\hline Q14 & S: Natural results & 3.00 & 3.80 \\
\hline
\end{tabular}

Table 2. An itemized evaluation of learning motivation

The results indicated that the mean for the group using web-learning environment was higher than that for the other group. Furthermore, the standard deviation for the group using web-learning environment had a smaller value than that of the other group. From the results, it was obvious that web-learning environment demonstrated an advantageous effect on enhancing learning motivation for the test-takers. The average scores of three attention-related factors also showed noticeable differences. The fact clarified that attention-related factors especially contributed the enhancement of learning motivation. From the results, motivation-oriented teaching method with problem-solving strategies is effective to design a web-learning environment with illustrative and explanatory materials in mechanical drawing class. A proper design with suitable contents can lead to enhancing learning motivation of learners. Moreover, the high completion rate is achievable with a proper design even when there is too much relevant knowledge to be learned. One of the possible factors helpful for achieving the high average scores in questionnaire investigation is also that the web-learning environment enabled us to learn something with keeping their paces.

Mann-Whitney $\mathrm{U}$ test was carried out to detect a significant difference in the results. The $\mathrm{U}$ value is 36 , and the two-sided asymptotic p-value was 0.001 . There was a significant difference between the two groups since the p-value was less than 0.05 . We also checked Cronbach's coefficient alpha for the validation of evaluation scale. As the result, the value of Cronbach's coefficient alpha was 0.988 in all the scales of 14 questions, so that internal consistency was confirmed by the value exceeding 0.90 .

\section{Conclusion and Future Work}

In this study, a web-learning environment with instruction of the third angle projection method was created based on motivation-oriented teaching method with problem-solving strategies. The web-learning environment was introduced into mechanical drawing class, and the effectiveness was investigated with the comparison of results from two types of evaluation tests. Then, the influence of web-learning environment on learning motivation was clarified by questionnaire investigation with a modified ARCS evaluation sheet. As a result, learning contents organized using Gagne's 9 events of instruction are invaluable for learning the essential knowledge in mechanical drawing. Moreover, a proper design with suitable contents can lead to enhancing learning motivation of learners. The high completion rate is also achievable with a proper design even when there is too much relevant knowledge to be learned.

Future research could focus on the relationship between usability and web-learning environment. In addition, further detailed investigations using the web-learning environment will be continuously made to accumulate research findings helpful for developing pedagogy and educational technology. 


\section{Declaration of Conflicting Interests}

The authors declared no potential conflicts of interest with respect to the research, authorship, and/or publication of this article.

\section{Funding}

This study was partially supported by JSPS KAKENHI Grant Number JP19K03063.

\section{References}

Adanez, G.P., \& Velasco, A.D. (2002). Predicting Academic Success of Engineering Students in Technical Drawing from Visualization Test Scores. Journal for Geometry and Graphics, 6(1), 99-109.

Al-Shalabi, H., Andraws, S., Alrabea, A.I., \& Kumar, A.V.S. (2012). V Model of E-Learning Using Gagne Nine Steps of Education. Journal of Software Engineering and Applications, 5, 850-854.

https://doi.org/10.4236/jsea.2012.511098

Arora, A.S., \& Sharma, A. (2018). Integrating the ARCS Model with Instruction for Enhanced Learning. Journal of Engineering Education Transformations, 32(1), 85-89.

Azodo, A.P. (2017). Attitude of engineering students towards engineering drawing: A case study. International Journal of Research Studies in Education, 6(1), 61-74. https://doi.org/10.5861/ijrse.2016.1401

Baba, J., Sale, P., \& Zirra, B. (2017). Applying Gagne's Nine Events in Designing a Multimedia Programme for Teaching Elements and Principles of Design in Secondary School. Arts and Design Studies, 54, 1-8.

Cheung, L. (2016). Using an Instructional Design Model to Teach Medical Procedures. Medical Science Educator, 26, 175-180. https://doi.org/10.1007/s40670-016-0228-9

dos Santos, E.F., Gonçalves, B.C.M., De Oliveira, K.B., \& Silva, M.B. (2018). Project Based Learning Applied to Technical Drawing. Creative Education, 9, 479-496. https://doi.org/10.4236/ce.2018.93034

Erlinda, N., \& Surya, E., (2017). Mathematical Learning Strategy of Fractional Form by Using Learning Model of Gagne and Human Figure Line Media. International Journal of Sciences : Basic and Applied Research (IJSBAR), 34(2), 13-22.

Halim, L., Yasin, R.M., \& Ishar, A. (2012). CAMED: An Innovative Communication Tool in Teaching Engineering Drawing. WSEAS Transactions on Information Science and Applications, 9(2), 58-67.

Hayashi, Y. (2013). Mechanical drawing. Jikkyo Shuppan Co., Ltd. (in Japanese).

Huerta, O., Kus, A., Unver, E., Aslan, R., Dawood, M., Kofoglu, M., et al. (2019). A Design-based Approach to Enhancing Technical Drawing Skills in Design and Engineering Education using VR and AR Tools. Proceeding the 14th International Joint Conference on Computer Vision, Imaging and Computer Graphics Theory and Applications. IVAPP: Prague, Czech Republic.

https://doi.org/10.5220/0007566003060313

Huett, J.B., Kalinowski, K.E., Moller, L., \& Huett, K.C. (2008). Improving the Motivation and Retention of Online Students Through the Use of ARCS-Based E-Mails. American Journal of Distance Education, 22(3), 159-176. https://doi.org/10.1080/08923640802224451

Katz, R. (2015). Integrating Analysis and Design in Mechanical Engineering Education. Procedia CIRP, 36, 23-28. https://doi.org/10.1016/j.procir.2015.01.042

Keller, J.M. (1987). Development and use of the ARCS model of instructional design. Journal of instructional development, 10(3), 2-10. https://doi.org/10.1007/BF02905780

Keller, J.M. (2010). Motivational design for learning and performance: the ARCS model approach. Springer. https://doi.org/10.1007/978-1-4419-1250-3 
Khadjooi, K., Rostami, K., \& Ishaq, S. (2011). How to use Gagne's model of instructional design in teaching psychomotor skills. Gastroenterol Hepatology from Bed and Bench, 4(3), 116-119.

Kurt, P.Y., \& Keçik, İ. (2017). The Effects of Arcs Motivational Model on Student Motivation to Learn English. European Journal of Foreign Language Teaching, 2(1), 22-44.

Kutlu, M.O., \& Menzi, N. (2013). The Effect of Implementation of Internet-Based Teaching Model Considers Gagne's Instructional Events Model in Information Technology Course for Primary (Elementary) Education to Academic Success and Retention. International Journal of Humanities and Social Science, 3(18), 169-179.

Lee, J., \& Kim, Y., (2012). Development of Web-based Courseware Applied ARCS Model. International Magazine on Advances in Computer Science and Telecommunications, 3(1), 33-43.

Lee, J., \& Lee, Y.J. (2012). Development and Application of E-Learning Content for Advertising Education. International Journal of Advanced Science and Technology, 47, 1-12.

Malik, S. (2014). Effectiveness of ARCS Model of Motivational Design to Overcome Non Completion Rate of Students in Distance Education. Turkish Online Journal of Distance Education, 15(2), 194-200. https://doi.org/10.17718/tojde.18099

Mei, F.S.Y., Ramli, S.B., \& Alhirtani, N.A.K.(2015). Application of Gagne's Nine Approaches to Teach Arabic Language for Non-Native Speakers: Experimental study at Sultan Idris Education University Malaysia (UPSI). European Journal of Language and Literature, 3(1), 32-37. https://doi.org/10.26417/ejls.v3i1.p32-37

Murakawa, Y., Sakaguchi, M., \& Imanaka, M. (2014). The effects of the introduction of Nintendo DS handheld software on learning and motivation. OCU journal of higher education studies, 12(1), 1-11 (in japanese).

Orji, R., Reilly, D., Oyibo, K., \& Orji, F.A. (2018). Deconstructing persuasiveness of strategies in behaviour change systems using the ARCS model of motivation. Behaviour \& Information Technology, 38(4), 319-335. https://doi.org/10.1080/0144929X.2018.1520302

Suzuki, K. (1995). On the Framework of Designing and Developing "appealing instruction" - The ARCS Motivational Model -. The Japan Association for Educational Media Study, 1(1), 55-61.

Suzuki, K. (2000). Encycropedia of educational technology. Kitaohji-Shobo (in japanese).

Wang, W., Ikeda, M., \& Li, F. (2007). Proposal and Evaluation of the "Motivational-Oriented" Teaching Method in Programming Education. Japan Society for Educational Technology, 31(3), 221.

Yasin, R.M., Halim, L., \& Ishar, A. (2012). Effects of Problem-solving Strategies in the Teaching and Learning of Engineering Drawing Subject. Asian Social Science, 8(16), 65-79.

https://doi.org/10.5539/ass.v8n16p65

Zhang, W. (2017). Design a Civil Engineering Micro-lecture Platform based on the ARCS Model Perspective. International Journal of Emerging Technologies in Learning, 12(1), 107-118. https://doi.org/10.3991/ijet.v12i01.6487

Published by OmniaScience (www.omniascience.com) Journal of Technology and Science Education, 2020 (www.jotse.org)

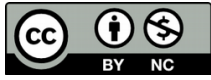

Article's contents are provided on an Attribution-Non Commercial 4.0 Creative commons International License. Readers are allowed to copy, distribute and communicate article's contents, provided the author's and JOTSE journal's names are included. It must not be used for commercial purposes. To see the complete licence contents, please visit https://creativecommons.org/licenses/by-nc/4.0/. 